\title{
STRATEGI KOMUNIKASI HUMAS DALAM MEMBENTUK CITRA PEMERINTAHAN DI KOTA BAUBAU
}

\author{
Hastuti $^{1}$ \\ Program Studi Ilmu Komunikasi, FISIP Universitas Muhammadiyah Buton \\ Email: hastutituo@gmail.com
}

\begin{abstract}
ABSTRAK
Humas memiliki peranan penting dalam setiap lembaga karena humas menjadi salah satu strategi dalam membentuk citra perusahaan baik itu citra positif maupun citra negatif. Dalam membentuk citra suatu lembaga, humas biasanya memiliki relasi yang luas. Penelitian ini bertujuan untuk mengetahui bagaimana strategi komunikasi Public Relations dan untuk mengetahui bagaimana hambatan-hambatan Public Relation di Bagian Humas Sekretariat Daerah Pemerintah Kota Baubau dalam membentuk citra pemerintahan. Jenis Penelitian ini menggunakan pendekatan deskriptif kualitatif. Hasil penelitian ini menunjukkan strategi komunikasi Public Relations di Bagian Humas Sekretariat Daerah Pemerintah Kota Baubau adalah dengan melaksanakan dua komunikasi adalah komunikasi internal dan komunikasi external. Hambatan-hambatan Public Relation di Bagian Humas Sekretariat Daerah Pemerintah Kota Baubau adalah sumber daya yang masih kurang memadai, besarnya biaya yang diperlukan serta kesulitan dalam kreatifitas. Untuk mencapai tujuan Humas Sekretariat Daerah Pemerintah Kota Baubau dalam membentuk citra pemerintahan maka diperlukan kerja keras, disiplin yang tinggi, kemampuan dan keahlian yang profesional dalam bidang Public Relation.
\end{abstract}

Kata Kunci: Strategi, Komunikasi Humas, Citra Pemerintahan

\section{PUBLIC COMMUNICATION STRATEGIES TO FORM GOVERNMENT IMAGES IN THE CITY OF BAUBAU}

\begin{abstract}
Public relations has a key role in any institution because of public relations into one strategy in shaping the company's image be it positive or negative image image. In shaping the image of an institution, the public usually has a broad relationship. This research aims to find out how the Public Relations and communications strategies to find out how the barriers Public Relation at the Government Secretariat Area Publicist Baubau in shaping the image of the Government. This type of research uses descriptive qualitative approach. The results of this research show the communication strategy Public Relations at the Government Secretariat Area Publicist Baubau is to carry out two communication is external communications and internal communications. Barriers Public Relation at the Government Secretariat Area Publicist Baubau is a resource that is still inadequate, the magnitude of the necessary costs and difficulties in creativity. To achieve the purpose of public relations Secretariat Government Area of Baubau in shaping the image of the Government then required hard work, discipline, skills and professional expertise in the field of battery whore public Relation.
\end{abstract}

Keywords: Communication strategies, public relations, Governmental Image 
Korespondensi: Hastuti, S.Sos., M.I.Kom. Universitas Muhammadiyah Buton. Alamat: Jl. Betoambari No. 36 Kota Baubau Sulawesi Tenggara kode Pos 93717. No. HP, WhatsApp: 085343630319 Email: hastutituo@gmail.com

\section{PENDAHULUAN}

Hubungan masyarakat (Humas) atau yang biasa disebut public relation (PR), menjadi hal yang tidak asing disetiap lembaga pemerintahan, lembaga pendidikan maupun lembaga perusahaan. Humas memiliki peranan penting dalam setiap lembaga karena humas menjadi salah satu strategi dalam membentuk citra perusahaan baik itu citra positif maupun citra negatif. Dalam membentuk citra suatu lembaga, humas biasanya memiliki relasi yang luas.

Dalam riset mengenai kegiatan humas (Public relations), ada dua tanggung jawab dalam kegiatan humas yaitu peran sebagai teknisi dan manajemen. Humas melaksanakan tiga peran, pertama sebagai pemberi penjelasan, yaitu orang yang bekerja sebagai konsultan dalam mendefenisikan masalah, menyarankan pilihan dan memantau implementasi kebijakan. Kedua sebagai fasilitator komunikasi, yaitu orang yang biasasanya bertugas dalam suatu organisasi yang berkaitan langsung dengan lingkungan yang berperan untuk menjaga hubungan dan komunikasi dua arah. Ketiga sebagai fasilitator pemecahan masalah, yaitu orang yang bermitra dengan senior untuk mengidentifikasi dan memecahkan masalah (Lattimore, 2010).

Fungsi humas sendiri tidak dapat terlepas dari opini publik, karena salah saru fungsi humas adalah menciptakan opini publik yang memiliki kemauan baik (good will) dan partisipasi. Kinerja humas dalam suatu pemerintahan biasanya membantu dalam menjalankan suatu program pemerintahan untuk mencapai tujuan tertentu yang ditargetkan oleh pemerintah. Selain itu, humas pemerintah juga berperan penting dalam membangun dan memberikan informasi baik secara internal maupun eksternal. Bila dilihat secara eksternal, biasanya humas berperan memberikan informasi mengenai kebijakan pemerintah, memberikan sanggahan mengenai suatu pemberitaan yang dapat merugikan pemerintah, dan menginformasikan berbagai kebijakan pemerintah kepada masyarakat.

Strategi humas yang dibangun seorang humas atau PR dapat menanamkan kepercayaan kepada publik tidak hanya untuk memperoleh citra positif. Tetapi citra positif yang sudah dibangun perlu dipertahankan, karena memiliki pengaruh dengan reputasi pemerintahan. Begitu kepercayaan publik luntur akibat reputasi negatif maka akan sulit bagi permerintahan untuk memulihkan kepercayaan tersebut.

Humas Kota Baubau sangat memiliki peranan penting dalam membentuk citra pemerintahan Kota Baubau. Dilihat dari kinerja yang dimiliki, humas Kota Baubau sangat bekerja keras dalam mempertahankan image pemerintahan Kota Baubau. Pemerintahan Humas Kota Baubau dalam mengembangkan hubungan yang baik dalam masyarakat dengan cara memberikan informasi karena keberadaan pemerintah Kota Baubau memiliki ketergantungan dalam hubungan dalam bermasyarakat sehingga ciitra pemerintah tetap terjaga. Selain itu, juga menciptakan pengertian publik yang lebih baik yang dapat memperbesar 
kepercayaan masyarakat terhadap pemerintah Kota Baubau. Humas Kota Baubau memiliki fungsi menyangkut upaya pembinaan citra (image), mulai dari upaya menumbuhkan citra, memelihara atau mempertahankan citra, sampai ke upaya untuk meningkatkan citra.

\section{METODE PENELITIAN}

Penelitian ini menggunakan jenis penelitian kualitatif. Penelitian kualitatif hendak menentukan pilihan perolehan sajian data dalam bentuk cerita rinci, mendalam dari para responden atau informan. Sementara itu, menurut Bogdan dan Taylor (Maleong,2008) menyatakan metode kualitatif digunakan sebagai prosedur penelitian yang dapat menghasilkan data deskriptif berupa kata-kata tertulis ataupun lisan dari orang-orang dan perilaku yang dapat diamati. Penelitian kualitatif bermaksud untuk memahami fenomena tentang apa yang di alami oleh subjek penelitian seperti prilaku, persepsi, motivasi, tindakan dan lain-lain, secara menyeluruh, secara holistic dan dengan cara deskripsi dalam bentuk kata-kata dan bahasa dengan memanfaatkan berbagai metode.

Dalam penelitian ini, jenis penelitian yang di gunakan adalah jenis penelitian kualitatif. Sehingga dalam penelitian ini cenderung menelah atau meneliti tentang strategi Public Relation (PR) Di Bagian Humas Sekretariat Daerah Pemerintah Kota Baubau dalam membentuk citra pemerintahan. Adapun pengambilan penelitian yang akan diamati dan diteliti yaitu Bagian Humas Sekretariat Daerah Pemerintah Kota Baubau.

Menurut Ruslan (2006), data merupakan fakta, fenomena, atau bahan-bahan keterangan dalam suatu penelitian yang dikumpulkan oleh peneliti yang kemudian diolah atau diproses. Dalam memperoleh data yang valid dan dapat di pertanggungjawabkan secara objektif, Ruslan (2006) membedakan ada dua sumber data yaitu: data primer dan data sekunder. Data primer biasanya diperoleh secara langsung, yaitu melalui proses wawancara langsung dengan narasumber sedangkan data sekunder Data sekunder adalah data yang diperoleh atau dikumpulkan oleh orang yang melakukan penelitian dari sumber-sumber yang telah ada. Data ini diperoleh dari buku-buku, laporan-laporan peneliti terdahulu,internet serta beberapa literatur penunjang dalam penelitian ini.

Menurut Sugiyono (2009), teknik pengumpulan data biasanya lebih banyak melakukan melalui observasi, berperan serta (partisipan observation), wawancara mendalam (in depth interview) dan dokumentasi. Metode pengumpulan data yang sangat erat kaitannya dengan masalah penelitian yang ingin dipecahkan. Masalah memberi arah dan mempengaruhi penentuan metode pengumpulan data.

Teknik pengumpulan data yang dilakukan dalam penelitian ini yaitu wawancara dan dokumentasi. Teknik wawancara yang dilakukan yaitu wawancara langsung kepada pihak badan Humas Pemerintahan Daerah Kota Baubau guna mendapatkan informasi yang lebih luas serta mendalam untuk dapat dijadikan bahan pembahasan dari hasil penelitian. Kemudian dalam proses penelitian ini, juga melakukan wawancara melalui email. Selain itu, dokumentasi yang dilakukan yaitu berupa sumber tertulis seperti buku, bahan laporan dan sebagainya. Dalam penelitian ini penulis akan mencari data- 
data otentik pendukung, baik dilakukan secara langsung, ataupun didapatkan dari sumber-sumber dari pihak-pihak terkait, di tempat penelitian di lakukan. Selain itu pendokumentasian dalam setiap kegiatan juga sangat penting sebagai bahan tambahan laporan hasil penelitian.

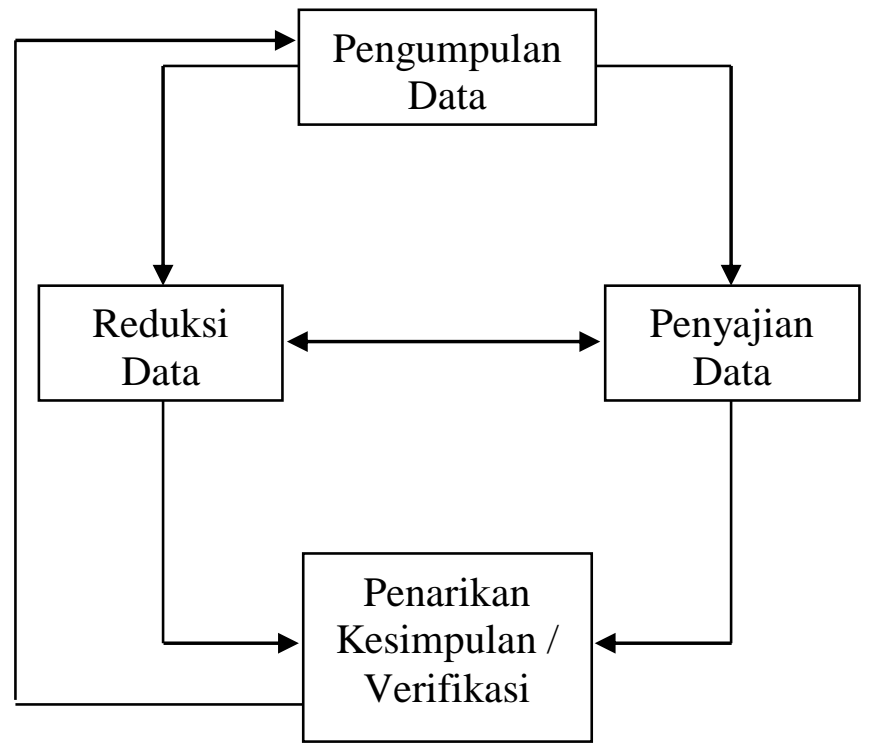

Gambar 3.1. Model Analisa Data

Kualitatis Milles \& Hubbermant Sumber : Suharsimi (2008)

Keabsahan data sangat mendukung dalam menentukan hasil akhir penelitian. Oleh karena itu, diperlukan beberapa teknik untuk memeriksa keabsahan data yaitu dengan menggunakan teknik triangulasi. Teknik triangulasi meliputi: a) triangulasi data, b) triangulasi peneliti, c) triangulasi metodelogis, d) triangulasis teoris. Peneliti ini menggunakan triangulasi data atau sumber.

\section{HASIL DAN PEMBAHASAN}

Humas Sekretariat Kota Baubau sebagai public relation adalah suatu proses komunikasi dua arah atau timbal balik (two-way communications) yang terencana baik intern maupun ekstern dalam usaha untuk menciptakan suatu hubungan yang harmonis yang bertujuan memperoleh goodwill, saling pengertian, public opinion, dan citra yang baik dari masyarakat. Tujuan dari public relation adalah untuk mengembangkan goodwiil dan memperoleh opini publik yang favourable, atau menciptakan kerjasama berdasarkan hubungan yang harmonis dengan berbagai publik. Artinya bahwa tujuan public relation adalah untuk menciptakan, membina dan memelihara sikap budi yang menyenangkan bagi lembaga/jawatan/organisasi, dan lain-lain disatu pihak, dan dengan pihak lain dengan jalan komunikasi yang baik dan puas secara timbal balik.

Meinanda (2008) membagi tujuan public relation sebagai berikut :

\section{Tujuan dari Internal Public relation}

Tujuan dari internal public relation adalah untuk mencapai karyawan yang mempunyai kegairahan kerja. Hal ini tersebut diwujudkan melalui :

a. Seorang pemimpin harus memperhatikan kepentingan-kepentingan para pegawai baik ditinjau dari ekonomi, sosial, maupun psikologis.

b. Membina "mental attitude" agar anggota atau karyawanya dapat memberikan kesan positif pada publik.

c. Memperlakukan tipe karyawannya dengan sikap yang sama, tanpa membedakan-bedakan tingkat, pendidikan, dan lain-lain.

d. Mengadakan upgrading atau memberi kesempatan untuk mengikuti pendidikan lainnya, yang secara psikologis dapat menaikan martabat mereka. 
2. Tujuan dari external Public relation

a. Untuk mempererat hubungan dengan orang diluar badan/instansi hingga terbentuklah opini publik yang favourable terhadap badan tersebut.

b. Mengadakan komunikasi yang efektif, yang sifatnya informatif dan persuasif, yang ditujukan kepada publik diluar badan tersebut.

Menurut Steinberg yang dikutip Meinanda (2008) tujuan public relation adalah untuk menciptakan publik yang favourable tentang kegiatan-kegiatan yang dilakukan oleh organisasi yang bersangkutan.

Public Relations / Humas Sekretariat Kota Baubau mempunyai peranan yang sangat penting bagi suatu organisasi, baik organisasi manufaktur maupun jasa. Seorang public Relations harus mampu menciptakan citra yang positif bagi perusahaan sehingga terbentuk pula opini publik yang baik. Peranan public relations bagi / Humas Sekretariat Kota Baubau terbagi menjadi dua, yaitu :

1. Kegiatan intern public relations / Humas Sekretariat Kota Baubau

Tujuan terpenting dalam intern public relations adalah mencapai dan mewujudkan pegawai yang mempunyai gairah kerja dan produktifitas kerja yang lebih baik. Sedangkan bentuk kegiatan intern public relations pada / Humas Sekretariat Kota Baubau harus lebih ditujukan untuk pengembangan pribadi dan meningkatkan kinerja.

2. Kegiatan ekstern public relations / Humas Sekretariat Kota Baubau
Kegiatan ekstern public relations yang dilakukan oleh public relations / Humas Sekretariat Kota Baubau rata-rata sudah cukup baik, dimana telah dijelaskan sebelumnya bahwa kualitas layanan yang diberikan setiap tahunnya mengalami peningkatan. Usaha-usaha untuk meningkatkan kualitas layanan yang dilakukan oleh Humas Sekretariat Kota Baubau dinilai sudah cukup berhasil selain terbukti dengan peningkatan kualitas layanan, juga dengan terciptanya opini publik yang positif dan citra yang baik bagi Humas Sekretariat Kota Baubau.

Kegiatan yang dilakukan melalui strategi komunikasi Public Relations/ Humas Sekretariat Kota Baubau harus lebih ditingkatkan lagi, setiap metode-metode kerja yang telah dilakukan oleh Public Relations/Humas Sekretariat Kota Baubau harus mampu menyelesaikan setiap masalah ataupun dalam menyelesaikan suatu pekerjaan serta kegiatan-kegiatan secara sistematis. Apabila timbul suatu permasalahan, maka pihak Public Relations/Humas Sekretariat Kota Baubau sesegera mungkin mencari solusi agar permasalahan cepat teratasi dengan baik.

Dalam upaya mempublikasikan dan meningkatkan citra pemerintahan di kota Baubau, upaya yang dapat dilakukan Public Relations/Humas Sekretariat Kota Baubau adalah dengan membangun image yang positif dalam relasi dengan masyarakat kota Baubau serta lembaga yang lain dan meningkatkan kinerja yang mengutamakan masyarakat kota Baubau . Lebih lanjut untuk meningkatkan citra, dapat dilakukan dengan langkah yang disampaikan oleh Djanaid (2003) bahwa untuk menciptakan citra yang baik 
diperlukan beberapa bentuk kerjasama dengan media massa yaitu :

1. Mengadakan kunjungan kekantor redaksi atau kantor-kantor berita untuk berkenalan dan menjalin hubungan baik. Mengundang wartawan untuk berkunjung kekantor, bentuk ini dapat dilakukan direstoran sambil makanmakan.

2. Konferensi pers

Suatu pertemuan antara satu organisasi/perorangan dengan pers.

3. Pers tour

Kegiatan mengajak wartawan meninjau keadaan lapangan dari kegiatan suatu organisasi.

4. Kursus latihan wartawan

Program ini bertujuan menambah wawasan tentang suatu masalah, misalnya hukum, politik, ekonomi, atau masalah-masalah yang bersifat teknis lainnya.

5. Sponsor artikel

Suatu bentuk kegiatan publikasi yang dilakukan oleh suatu organisasi melalui penulisan artikel/berita.

6. Wawancara pers

Bentuk kegiatan ini dalam rangka kepentingan dengan wartawan surat kabar secara khusus. Inisiatif wawancara ini adalah dari pihak wartawan sendiri, baik atas inisiatif sendiri maupun atas perintah pemimpin redaksi.

7. Iklan

Bentuk kegiatan ini dalam rangka kepentingan suatu perusahaan/instansi. Dapat dalam bentuk pengumuman, promosi dan lain-lain. Untuk itu instansi yang bersangkutan dikenakan biaya menurut ketentuan.

Dari penjelasan di atas dapat diketahui, bahwa kegiatan-kegiatan yang telah dilakukan oleh Public Relations/Humas Sekretariat Kota Baubau untuk merubah opini publik dalam meningkatkan citra pemerintah sudah cukup berhasil dengan baik. Sebagai langkah berikutnya terkait dengan strategi komunikasi Public Relations / Humas Sekretariat Kota Baubau, maka diperlukan metode kerja sebagaimana yang disebutkan Ruslan (2005) yaitu :

1. Research/Penelitian

Sebelum melakukan komunikasi pada masyarakat, petugas public relation harus mengetahui lebih dahulu siapa yang akan diberi pesan dan bagaimana keadaan komunikasi. Untuk itu perlu dilakukan penelitian, sebab hal ini penting untuk mendapatkan faktor dari publik. Tanpa mengetahui dari keadaan publik, maka komunikasi yang dilakukan oleh petugas public relation tidak mengenai sasaran. Ada beberapa teknik penelitian dalam public relation, yaitu :
a. Survey
b. Studi kasus
c. Analisa kegiatan
d. Analisa dukumen
e. Penelitian "follow-Up"

\section{Planning/Perencanaan}

Setelah mendapatkan fakta-fakta/ data-data dari hasil penelitian, langkah selanjutnya adalah membuat perancangan yang tepat, sehingga mencapai sasaran yaitu merebut public opinion. 
Beberapa hal yang perlu dirumuskan dalam perancangan adalah:

a. Dasar-dasar pemikiran

b. Sasaran

c. Kegiatan

d. Lokasi

e. Waktu

f. Tujuan

g. Organisasi pelaksana

h. Materi

i. Biaya

j. Time schedule

3. Action/Kegiatan

Setelah rencana cukup matang dan disetujui oleh pihak yang berwenang, maka rencana tersebut dilaksanakan. Dalam pelaksanaan kerja ini adalah mengkoordinasikan antara:
a. Tenaga kerja
b. Dana
c. Alat kerja
d. Lokasi dan lingkungan
e. Waktu

\section{Evaluation / Evaluasi}

Tahap ini dimaksudkan untuk mencocokan sampai dimana program atau rencana yang telah dilaksanakan. Pada tahap ini petugas public relation mengadakan penilaian mengenai:

a. Apakah semua program dapat dilaksanakan seluruhnya.

b. Apakah kesulitan-kesulitan yang dialami selama kegiatan.

c. Apakah pesan-pesan yang disampaikan sesuai yang diinstruksikan.

d. Apakah kegiatan yang dilakukan sudah efisien. e. Apakah tujuan dalam merebut public opinion dapat tercapai.

Lebih lanjut dalam upaya meningkatkan metode pekerjaan public relation/Humas Sekretariat Kota Baubau yang dapat digunakan menurut Aitchison (2005) yaitu :

1. Penelitian opini publik: mengungkapkan apa pendapat orang yang sebenarnya tentang perusahaan klien.

2. Penelitian citra: menyelidiki citra korporat secara mendalam, menunjukan bagaimana perusahaan itu dipandang dan seberapa baik kebijakanya dipahami.

3. Penelitian motivasional: menyelidiki faktorfaktor psikologis yang membentuk sikap orang terhadap perusahaan dan kebijakanya.

4. Penelitian efektifitas: mengukur pengaruh program public relation atas khalayak sasaran.

5. Analisis kandungan: meninjau ulang apa yang dikatakan oleh media massa tentang perusahaan klien serta bagaimana mereka memperlakukan kisah tersebut dan memberi warna pada kisah itu.

6. Audit public relation: menyelidiki setiap aspek kegiatan public relation perusahaan secara internal dan external.

Peranan Public relation dahulu dan saat ini selalu mengalami perubahan, dahulu PR berperan sebagai event organizer. Sedangkan saat ini, seorang public relation harus bisa membuka peluang dalam membangun investasi dan membaca peluang pasar serta pelayanan yang dibutuhkan masyarakat. Bidang komunikasi dan public relation kini menjadi salah satu kunci terpenting yang berperan dalam suatu industri dan 
jasa untuk bersaing pada era saat ini. Hal ini, karena setiap sektor industri maupun jasa akan saling bersaing menciptakan image positif sehingga dapat memberikan inovasi yang terbaru dan terpercaya. Dalam era globalisasi public relation akan sangat berperan, apabila organisasi tidak memanfaatkan bidang public relation tersebut bakal tertinggal karena tidak menguasai perolehan dan penyebaran informasi.

Salah satu peranan dari public relation adalah memperoleh opini publik yang favourable. Apabila opini publik terhadap suatu perusahaan terkesan menyudutkan maka tugas public relation adalah mempengaruhi opini publik tersebut agar dapat menjadi opini publik yang menguntungkan. Pada dasarnya opini publik terbentuk dari hasil interaksi antara sikap-sikap individu dengan keyakinannya masing-masing mengenai suatu persoalan. Selain itu opini publik tidak berasal dari satu pendapat perseorangan saja, melainkan dari hasil diskusi suatu kelompok individu. Opini publik yang positif pada dasarnya merupakan opini publik yang mampu membentuk hubungan yang harmonis dan goodwill suatu organisasi/ perusahaan. Seperti telah diketahui sebelumnya bahwa opini publik dapat berubah setiap saat. Dengan kata lain opini publik itu dapat dibentuk atau dipengaruhi untuk mencapai salah satu tujuan utama kegiatan public relation, yaitu mendapat goodwiil dari mayarakat, untuk itu diperlukan suatu usaha tersendiri untuk mempengaruhi opini publik tersebut.

\section{SIMPULAN}

Penelitian skripsi dengan judul Strategi Komunikasi Humas Dalam Membentuk Citra
Pemerintahan Kota Baubau di Bagian Humas Sekretariat Daerah Pemerintah Kota Baubau, menyimpulkan bahwa :

1. Strategi komunikasi Public Relations di Bagian Humas Sekretariat Daerah Pemerintah Kota Baubau dalam membentuk citra pemerintahan, adalah dengan melaksanakan dua komunikasi yaitu komunikasi internal dan komunikasi external. Dalam komunikasi internal dilakukan dengan cara menggerakan seluruh pegawai dan karyawan agar memberikan service atau pelayanan yang baik pada masyarakat dan untuk bekerja lebih produktif dan efisien, Sedangkan komunikasi eksternal dilakukan dengan cara membuat press release oleh staf, yang dibuat sesuai dengan kebutuhan wartawan dan berusaha untuk memberikan layanan kepada masyarakat dengan sebaik mungkin tanpa membedabedakan status ekonomi dan sosial masyarakat yang dilayani sesui Standar Operasinal Pelayanan yang telah ditetapkan.

2. Hambatan-hambatan Public Relation di Bagian Humas Sekretariat Daerah Pemerintah Kota Baubau dalam membentuk citra pemerintahan, maka Perlu meningkatkan kreatifitas dan inovasi yang lebih baik untuk mencapai tujuan yaitu dengan meningkatkan kualitas dan kuantitas sumber daya manusia yang profesional dalam bidang Public Relation sehingga dapat melaksanakan rencana dan kebijakan yang telah ditetapkan dengan kreatifitas dan inovasi yang tinggi. Guna 
membangun dan meningkatkan citra yang lebih baik maka Public Relation harus meningkatkan peranannya yaitu dengan meningkatkan opini dan image yang lebih baik. Upaya-upaya yang dapat dilakukan antara lain dengan merencanakan dan melaksanakan program yang membangun citra pemerintahan, antara meningkatkan program sosial kemasyarakatan, baik yang dilaksanakan oleh masyarakat, LSM maupun pemerintah setempat serta meningkatkan kualitas layanan melalui layanan yang prima oleh Humas Sekretariat Daerah Pemerintah Kota Baubau.

\section{SARAN}

1. Sehubungan dengan hasil penelitian dan kesimpulan yang telah dipaparkan terhadap Strategi Komunikasi Humas Dalam Membentuk Citra Pemerintahan Kota Baubau di Bagian Humas Sekretariat Daerah Pemerintah Kota Baubau, maka disarankan Untuk meningkatkan strategi komunikasi Public Relations di Bagian Humas Sekretariat Daerah Pemerintah Kota Baubau dalam membentuk citra pemerintahan, maka perlu dilakukan upaya meningkatkan kemampuan, ketrampilan dan keahlian pegawai yang didukung oleh disiplin kerja yang tinggi, motivasi kerja yang bagus serta memiliki wawasan yang luas dengan memberikan pendidikan dan pelatihan bidang public relation, agar dapat melaksanakan tugas dengan lebih baik dan juga perlu dilakukan rencana dan evaluasi program-program public relation agar dapat mencapai hasil yang baik serta tugas seorang Public relations harus pula menyusun dan membuat rencana serta kebijakan yang dapat dijadikan acuan dalam pencapaian tujuan meningkatkan citra pemerintah secara konkret dengan pelayanan yang prima.

\section{DAFTAR PUSTAKA}

Aitchison, Jim \& Lwin, May. (2005). CLUELESS IN PUBLIC RELATION. Diterjemahkan oleh Jusupadi. PT. Bhuana Ilmu Populer, Kelompok Gramedia. Jakarta.

Djanaid, Djanalis. (2003). PUBLIK RELATION DALAM TEORI DAN PRAKTEK. Edisi VII (Revisi). Indopurels Training. Malang.

Lattimore. (2010). PUBLIC RELATION PROFESI \& PRAKTEK. Selemba Humanika.

Meinanda, Teguh. (2008). TANYA JAWAB DASARDASAR PUBLIK RELATION. Cetakan Kedua, Armico. Bandung.

Moleong, Lexy J. (2008). METODELOGI PENELITIAN KUALITATIF. Bandung : PT.BPK Gunung Mulia

Ruslan, Rosady. (2006). MANAJEMEN PUBLIC RELATOINS \& MEDIA. Komunikasi. Jakarta : PT Rajagrafindo Persada

(2005). MANAJEMEN PUBLIC RELATION DAN MEDIA KOMUNIKASI. Jakarta: Raja Grafindo Persada

Suherman, A., \& Sirajuddin, A. (2018). KEARIFAN LOKAL SEBAGAI BASIS KOMUNIKASI PEMERINTAH DALAM PENYELESAIAN KONFLIK SOSIAL DAN KOMUNAL. DIALEKTIKA: Jurnal Ekonomi dan Ilmu Sosial, $3(2), 34-42$.

Sugiyono. (2009). METODELOGI PENELITIAN KUANTITATIF KUALITATIF. Bandung: Alfabeta. 